\title{
Om Grundtvigs udviklingslære - og noget om Darwins
}

\section{Af Ove Korsgaard}

'Udvikling' indgår som en grundkategori i såvel Grundtvigs som Darwins udviklingslære, dog med den afgørende forskel, at Grundtvig primært er optaget af historiens udviklingslove, hvorimod Darwin er optaget af naturens udviklingslove. Gennem en stor del af Grundtvigs forfatterskab kan man følge hans tofrontskrig mod såvel materialismen som idealismen. Hvad han søgte, var en tredje position og dermed en anden måde at forstå naturen på end den dominerende $\mathrm{i}$ såvel teologien som naturvidenskaben. Med udgangspunkt i afhandlingen "Om Mennesket i Verden" fra 1817 skitseres Grundtvigs udviklingslære, der bygger på en forestilling om naturens verden opbygget som en trappe, hvor de enkelte trin rummer hver deres kvaliteter. Mineralriget rummer form, blomsterriget desuden liv, dyreriget desuden bevidsthed og menneskeriget desuden selvbevidsthed. Vekselvirkningen mellem 'hånd og mund' - mellem håndens griben og sprogets begriben - ser Grundtvig som drivkraft bag udvikling af selvbevidsthed. Som epilog til artiklen inddrages Jesper Hoffmeyer, der stiller spørgsmålet, om Darwin med sin udviklingslære har givet en udtømmende forklaring på evolutionen. Selv nægter han at skulle vælge mellem at tro på en natur, som det er fuldstændig umuligt at føle sig hjemme i som åndeligt væsen, og på den anden side, at mennesket har fået sjælen pustet ind af Gud.

I 1859 udgav den engelske naturforsker Charles Darwin sit berømte skrift $O n$ the origin of species by means of natural selection, hvori han fremsatte den teori, at alle planter og dyr havde udviklet sig fra få oprindelige former til nutidens myriader af arter. Selv om Darwin i dette værk kun i kryptiske vendinger beskæftigede sig med menneskets oprindelse, blev hans udviklingslære meget hurtigt omtalt som 'abeteorien'. Det er først i The descent of man, and selection in relation to sex fra 1871, at Darwin selv skrev om menneskets udvikling og her udfoldede, hvordan han mente, at mennesket havde udviklet sig fra abelignende forfædre. Darwins teorier kastede verden ud i en stadig standende diskussion: nedstammer vi fra aber eller Adam? Grundtvig holdt på Adam, Darwin på aberne. I dag er det de færreste i Danmark (men ikke i for eksempel USA ${ }^{1}$ ), der er af den opfattelse, at mennesket stammer fra Adam, langt de fleste er darwinister i den forstand, at vi tilslutter os den anskuelse, at mennesket ikke bare har fælles forfædre med aber, men også med fisk og andre hvirveldyr, ja, endda med

1 Jf. Hjermitslev 2009, 202. 
encellede organismer. Selv om Grundtvig umiddelbart ser ud til at have lidt et totalt nederlag til Darwin, er der stadig grund til at interesse sig for Grundtvigs udviklingslære og hans antropologi. Nok har Darwins evolutionslære fjernet grunden under nogle af Grundtvigs antagelser, men darwinismen har langtfra fjernet hele grunden. For at belyse og aktualisere Grundtvigs antropologi vil jeg inddrage en række videnskabsmænd og filosoffer fra det tyvende århundrede.

Til indledning først et par overvejelser over begrebet 'udvikling'. Det er ikke kun Darwin, der formulerede en udviklingslære, det gjorde Grundtvig også. I de ofte citerede linjer fra indledningen til Nordens Mythologi fra 1832, fremhæver Grundtvig, at mennesket ikke er skabt til at efterabe til evig tid, men til at udvikle sig i tiden:

Mennesket er ingen Abekat, bestemt til først at efterabe de andre Dyr, og siden sig selv til Verdens Ende, men han er en mageløs, underfuld Skabning, i hvem Guddommelige Kræfter skal kundgiøre, udvikle og klare sig giennem tusinde Slægter, som et Guddommeligt Experiment, der viser, hvordan Aand og Støv kan giennemtrænge hinanden, og forklares i en fælles guddommelig Bevidsthed. Saaledes maa Mennesket opfattes, naar der skal blive en aandig Videnskabelighed paa Jorden. $^{2}$

Hvis vi leger lidt med tallene og sætter et slægtled til 30 år, udfolder Grundtvig her et tidsperspektiv på menneskehedens historie på ikke mindre end 30.000 år.

I det hele taget er det ikke først med Darwin, at 'udvikling' bliver et centralt begreb. Inden for biologien skete det allerede halvtreds år før Darwin, da Jean Baptiste Lamarck i 1809 fremsatte en videnskabelig teori om livet som et produkt af evolution, der er opstået på baggrund af naturlige love. Lamarck var en af de første til at bruge begrebet biologi i dets moderne betydning. ${ }^{3}$ Udvikling udgjorde også kernen i den såkaldte 'universalhistoriske vending', der brød igennem $\mathrm{i}$ slutningen af 1700-tallet. Dermed blev historie en dimension ved alt, intet kunne forstås uden at forstås historisk. Universalhistorien som en ny, fremherskende bevidsthedsform begyndte med Johann Gottfried Herder og kulminerede med G. W. F. Hegel, der hævdede, at verdens mening er dens historie. Ligesom Herder og Hegel bidrog Grundtvig i høj grad til denne universalhistoriske vending.

Før den universalhistoriske vending i slutningen af 1700-tallet var de fleste historikere overbevist om rigtigheden af, at fortiden var knap 6000 år. Den irske ærkebiskop James Ussher, der levede 1581-1656, havde beregnet, at verden var skabt natten til den 23. oktober år 4004

US V, 408.

Bowler 2009. 
f.Kr. Udgangspunktet for beregningerne af fortidens længde var Bibelen. Men frem for at bruge den bibelske skabelseskronologi som disposition indledte Herder sit store værk Ideen zur Philosophie der Geschichte der Menschheit med sætningen: "Unsre Erde ist ein Stern unter Sternen" (Vor Jord er en stjerne blandt stjernerne). ${ }^{4}$ Med udgangspunkt $i$ astronomien udfolder han billedet af jorden som en lille del af et stort kosmisk drama. Som noget nyt betragter Herder historien som formdannende udviklingsprocesser, der også virker i naturen. "Die Kraft, die in mir denkt und wirkt, ist ihrer Natur nach eine so ewige Kraft als jene, welche die Sonnen und Sterne zusammenhält" (Den kraft, som tænker og virker i mig, er efter sin natur i overensstemmelse med en lige så evig kraft som den, der holder sol og stjerner sammen). ${ }^{5}$ I værket gennemgår Herder først Jordens stilling i universet, dernæst plantelivet, så dyrelivet, og derefter menneskelivet, herunder menneskets stilling blandt dyrene.

Grundtvig er den historiker i Danmark, der mest direkte skrev universalhistorie $\mathrm{i}$ forlængelse af den tyske tradition. Ligesom for Herder og Hegel var historie også for Grundtvig en helt grundlæggende dimension ved menneskelivet: "al sand Vidskab [OK: her forstået som vidensfilosofi] maae i alle Maader være historisk;(...) historisk, fordi Mennesket udvikler sig i Tiden og kan kun begribes i den." Grundtvig bidrog i høj grad til udvikling af den universalhistoriske bevidsthedsform. Selv om universalhistorie ikke er evolutionshistorie, er der et slægtskab i synet på udvikling som et resultat af en bestemt udviklingsmekanik.

'Udvikling' kan således siges at indgå som en grundkategori i såvel Grundtvigs som Darwins udviklingslære, om end der er den afgørende forskel, at Grundtvig primært er optaget af historiens udviklingslove, hvorimod Darwin er optaget af naturens udviklingslove. Denne forskel rejser spørgsmålet om forholdet mellem historie og natur. Er historien og mennesket blot et produkt af naturens udviklingsmekanik? Eller rummer historien dimensioner, som ikke fuldt ud kan forklares ved at studere naturen ved hjælp af naturvidenskabelige metoder?

4 Herder 1877-1913, XIII, 13.

5 Ibid., 16.

6 DV 1816, 120. 


\section{Grundtvig som videnskabsmand}

Det kan være vanskeligt at få hold på Grundtvigs forhold til videnskaber om naturen. På nogle punkter synes han uhyre gammeldags; for eksempel holdt han fast $\mathrm{i}$ det såkaldte ptolemæiske verdensbillede, hvori Jorden er universets centrum, og afviste dermed Kopernikus' heliocentriske verdensbillede. Men før man dermed afskriver ham som snæversynet og forstokket, er det værd at lytte til hans argumentation for at fastholde det ptolemæiske verdensbillede. Det gør han, fordi vores måde at sanse verden på er i overensstemmelse med det ptolemæiske verdensbillede, ikke det kopernikanske. Mens det første kan sanses, kan det andet ikke. Det er en abstraktion. Fænomenologisk set lever vi stadig i den verden, Ptolemæus har beskrevet. Vi sanser verden med jorden som udgangspunkt. Vi ser solen står op, ikke jorden. Formuleret ved hjælp af moderne sprogbrug er det geocentriske verdensbillede lig med livsverden og det heliocentriske med systemverden. Når Grundtvig foretrak det ptolomæiske verdensbillede, var det for at fastholde livsverdenen som den egentlige verden, en verden, der er sansbar. ${ }^{7}$

I Grundtvigs forfatterskab kan man finde skarpe udfald mod en række naturvidenskabelige discipliner. I sine yngre dage hævdede han ligefrem, at der hvor kemi, astronomi og matematik blomstrer og agtes som de ypperste videnskaber, der er det åndelige træ sin undergang nær. ${ }^{8}$ Men i forfatterskabet findes der også positive henvisninger til de selv samme discipliner. I Nordens Mythologi formulerede han næsten en kærlighedserklæring til naturvidenskaben:

Astronomi, Botanik og Mineralogi, ja, selv Grammatik, Chemi og Mathematik, der vel poetisk maa kaldes de sex Vand-Kar af Steen, blive[r] til en aaben Vin-Kielder, der har det store Fortrin, at ligesaa fort som Man øser Vand i, kan man tappe Vin ud, og det en Vin der baade vederkvæger Flere, smager bedre, og beruser mindre end den Forrige. $^{9}$

Heller ikke i skriftet Om Nordens videnskabelige Forening (1839) ekskluderede han naturvidenskab og matematik. Tværtimod: Ved et frit nordisk universitet "vilde Collegierne eller Museerne være deelt mellem de Historiske og de Physiske Videnskaber, for at samle Kræfterne paa begge Sider til den stærkest muelige Anstrængelse og Vexelvirkning”. Der vil selvfølgelig være en vis modsætning mellem de historiske og de fysiske videnskaber, siger Grundtvig, men da

Jf. Pedersen 1989-90.

US II, 343.

9 US V, 446, jf. Joh 2,6-9. 
"Universal-Historien" omfatter hele den menneskelige virksomhed, omfatter den også "alle Menneske-Slægtens videnskabelige Bestræbelser". ${ }^{10}$

Da det femte skandinaviske naturforskermøde blev afviklet i København i dagene 12.-18. juli 1847, var Grundtvig inviteret med på udflugten til Roskilde, hvor han på talerstolen i palægården talte varmt til forsamlingen om et venligt forlig mellem natur og historie, om end han fastholdt, at det, der i særlig grad knytter de nordiske folk sammen, er historien. Til festmiddagen havde han skrevet en drikkevise, hvor han priste vinen, selv om druerne kom fra Rhinen! Han sluttede visen med følgende opfordring: "Derpaa vi tømme vil nu med en Fart / Et Velkomstbæger dybt af nordisk Art!". 11

At Grundtvig fra tid til anden forholder sig endog meget kritisk til naturvidenskab, betyder ikke, at han tager afstand fra at undersøge naturen ved hjælp af naturvidenskabelige metoder. Hvad han tager afstand fra, er at tilkende videnskaber om naturen en privilegeret position i forhold til videnskaber om mennesket. For Grundtvig repræsenterer naturvidenskab og menneskevidenskab forskellige metoder til at undersøge forskellige virkelighedsniveauer, nemlig det som Grundtvig kaldte det 'udvortes' og det 'indvortes', dvs. det synlige og det usynlige niveau.

Iklædt en anden sprogdragt genfindes samme tankefigur i nyere hermeneutisk filosofi, når det her understreges, at det er umuligt at forstå selvet og identitet på linje med genstande, som vi videnskabeligt kan identificere. Vi kan skaffe os viden om mennesker ved at dissekere lig, men ingen videnskabelig fremgangsmåde gør det muligt at finde en persons selv og en persons identitet. Disse fænomener kan ikke gribes og undersøges ved hjælp af naturvidenskabens målemetoder, de kan kun begribes. Den canadiske filosof Charles Taylor hævder således i Sources of the Self (1989):

et selv eller en person (...) har ikke karakter af et objekt $\mathrm{i}$ den almindelige betydning af termen. Vi er ikke et selv på samme måde, som vi er organismer, eller vi har ikke et selv på samme måde, som vi har hjerter eller levere. Vi er levende væsner med disse organer uafhængigt af vore selv-forståelser eller -tolkninger. (...) Men vi er kun et selv for så vidt som, at vi befinder os inden for rammerne af bestemte spørgsmål. (...) Selvet er til dels konstitueret gennem dets selv-fortolkninger.

$10 G S k v$ II, $148 \mathrm{f}$.

11 PS V, 640. 
Men også kun til dels. I Taylors optik kan man nemlig ikke være et selv for sig selv. Et selv kræver ‘en anden’:

Jeg er kun et selv i forhold til bestemte samtalepartnere (...). Et selv eksisterer kun inden for rammerne af (...) 'samtalenetværk'. Det er dette basale forhold, der ligger til grund for vort begreb om 'identitet', idet det byder på et svar på spørgsmålet om, hvem jeg er, ved at definere, hvorfra jeg taler og til hvem. ${ }^{12}$

Identitet er ikke blot et produkt af min egen livshistorie, den er også et produkt af, at min egen livshistorie er flettet sammen med andre livshistorier. Selv om ingen videnskabelig fremgangsmåde gør det muligt at finde selvet, er det nødvendigt at tilkende mennesket et selv. Den franske filosof Paul Ricæur har på elegant vis formuleret det synspunkt, at det er nødvendigt at tale om os selv - som et selv. ${ }^{13} \mathrm{Og}$ dét selv om selvet er et usynligt fænomen, som ingen videnskabelig fremgangsmåde har kunnet identificere.

Grundtvig fastholdt gennem hele livet menneskevidenskab som den afgørende videnskab, fordi den rummer større forklaringskraft om livet end naturvidenskab. Med andre ord: Menneskevidenskaben kan forklare mere om naturen, end naturvidenskaben kan forklare om mennesket. Naturen indgår imidlertid som et drilagtigt fænomen $\mathrm{i}$ begge videnskaber, idet legemet jo er et stykke natur, der kan undersøges og analyseres ved hjælp af naturvidenskabelige discipliner. Hvordan så Grundtvig på legemet? Betragtede han det som besjælet eller beåndet? $\mathrm{Og}$ hvad vil det i givet fald sige?

Disse spørgsmål tog Grundtvig op til filosofisk behandling $\mathrm{i}$ Danne-Virke-skrifterne 1816-19. Hans verdensbillede bygger på en lang tradition inden for kristen teologi, hvor kristendom og videnskabelig tænkning ikke står i modsætning til hinanden. ${ }^{14}$ Oldkirkens bestræbelser på at tænke kristendom og videnskab sammen virkede frem til 1700-talet. Det er først i oplysningstiden, at der for alvor rokkes ved kristendommens selvfølgelige status. Dog fortsætter Grundtvig med at forfægte det synspunkt, at kristendom og videnskab ikke står i et oppositionelt forhold til hinanden. Og det gør han ved at skelne mellem kristendom som tro og kristendom som den "eneste sikkre og trovardige Veiledning til sand Vidskab". ${ }^{15}$ Her lægges grunden til den skelnen, hvorom han senere i Nordens Mythologi brugte kategorierne 'kristen åbenbaring' og 'kristen anskuelse'.

\footnotetext{
12 Sources of the Self 1989, citeret fra Jensen 2003, 92 og 233.

13 Kemp 2001, 12 ff.

14 Jf. Pedersen 2000.

15 DV II, 202.
} 
I afhandlingen "Om Mennesket i Verden", som indgår i DanneVirke II 1817, finder man en skitse til et natursyn, nærmere bestemt til en systematisering af naturrigerne og menneskets placering i disse riger. Her ses naturen som et netværk af betydninger, af tegn, der alle finder deres forklaring i det menneskelige legeme, der igen finder sin forklaring i den menneskelige selvbevidsthed. Grundtvig ændrede holdning til mange ting gennem sit lange liv, men filosofisk fastholdt han det syn på mennesket, han udarbejdede i Danne-Virke-skrifterne 1816-19.

\section{To skoler}

I Grundtvigs ungdom var europæisk filosofi delt i to skoler: 'atomisterne' og 'dynamisterne'. ${ }^{16}$ Forenklet kan man sige, at 'atomisterne' var præget af den naturforståelse, at ånd og natur er to adskilte verdner: ånd er frihed, menneskets vilje og ansvar, natur er naturlovenes uforanderlighed og ufrihed. Dette natursyn havde baggrund $\mathrm{i}$ den epokegørende udvikling, der var sket inden for naturvidenskaben i 1600-tallet og 1700-tallet symboliseret af navne som Galilei, Kopernikus, Kepler og Newton. Inden for idé- og videnskabshistorie taler man om "verdensbilledets mekanisering", hvilket kommer til udtryk i en lang række beskrivelser af verden som et urværk eller som en velfungerende maskine. For eksempel fraskrev den franske filosof René Descartes i første halvdel af 1600-tallet dyrene enhver psykisk virksomhed, de var blot vidunderligt indrettede maskiner. Det, der gør mennesket til menneske, er tænkningen, hvilket han formulerede i det berømte slogan: cogito, ergo sum, dvs. jeg tænker, altså er jeg til. Menneskets legeme er blot en kompliceret maskine, men i modsætning til dyrene er der koblet tænkningen til den. Men hvordan forbindelsen mellem det synlige legeme og den usynlige tænkning skal forstås, efterlod Descartes i virkeligheden som et uafklaret problem. Den franske læge La Mettrie søgte med bogen L'homme machine (1747) at skære igennem problemstillingen ved at mekanisere det menneskelige sjæleliv og føre alle psykiske funktioner tilbage til fysiske. I den forbindelse sammenlignede La Mettrie mennesket med chimpansen.

Men i slutningen af 1700-tallet fik den anden skole, 'dynamisterne', for alvor vind i sejlene. J. W. Goethe begyndte at tale om natur som individuationsproces: Naturen kan i sidste instans ikke udforskes objektivt gennem videnskab, men kun fuldt ud opleves subjektivt. Hos den tyske filosof Fr. W. J. Schelling var naturen den synlige ånd og 
ånden den usynlige natur. Mens oplysningstidens mænd opfattede naturen som noget dødt og mekanisk, kunne mennesket ifølge den schellingske naturfilosofi opdage sit eget ansigt i naturens spejl. Naturen er først og fremmest 'liv'. Der findes ingen død materie og derfor ingen uoverstigelig kløft mellem organisk og uorganisk natur. En og samme guddommelige kraft går gennem naturen, historien og videnskaben. Det var Schellings naturfilosofi, som geologen og filosoffen Henrich Steffens tog afsæt i, da han med sine forelæsninger i København 1802-04 introducerede romantikken i Norden. I Danmark kæmpede fysikeren H. C. Ørsted livet igennem for en dynamisk opfattelse af naturen, om end han forholdt sig kritisk til visse sider af Schellings naturfilosofi. ${ }^{17}$ Titlen på hans hovedværk er Aanden $i$ Naturen I-II 1850-51.

Et stykke af vejen slår Grundtvig, romantiker som han jo var, følge med naturfilosoffer som Schelling. I Krønikens Gienmaele (1813) skrev han, at Schelling havde "opdaget den oprindelige Eenhed mellem det Udvortes og Indvortes" - en betragtningsmåde, Grundtvig tilsluttede sig. ${ }^{18}$ Det er derfor ikke overraskende, at Grundtvig endnu i 1855 vendte sig vredt mod La Mettries opfattelse, at alle sjælelivets facetter kan føres tilbage til fysiske funktioner: "den splittergale, umenneskelige Betragtning af Mennesket som en blot Maskine, og Betragtningen af Menneske-Aanden og Menneske-Hjertet, hvoraf Menneske-Livet udspringer, som Fostre af en gammel Overtro, der skal aflægges". ${ }^{19}$ Men selv om han tog skarpt afstand fra en mekanisk og materialistisk betragtning af mennesket, tilsluttede han sig langtfra en idealistisk. For Grundtvig fører naturfilosofiens idealisme uvægerligt til, at ånden i hovmod hæver sig over naturen, herunder menneskets egen natur. Grundtvig anklager således naturfilosofien for at bygge på en reduktionistisk forståelse af tilværelsen. Mens materialismen søger at reducere alt til det materielle niveau, søger idealismen at ophøje alt til det åndelige niveau. Men dermed bliver der tale om en omvendt form for reduktionisme. I det første tilfælde klappes verden sammen til ren materie, $\mathrm{i}$ det andet tilfælde til ren ånd. Men, siger Grundtvig i Danne-Virke-skriftet "Om Videnskabens Forhold til Erfaringen og sund Menneskeforstand":

det er jo unægteligt at Mennesket bestaaer af noget Legemligt og noget Aandeligt som tilsammen udgiøre Eet, sammensmelte i SelvBevidstheden der jo hverken giælder blot vor legemlige eller blot vor

17 Jf. Christensen 2009. 
aandelige, men vor menneskelige Tilværelse - den fornuftige Personlighed - der er et Samfund af begge. ${ }^{20}$

For Grundtvig kommer selvbevidstheden i særlig grad til udtryk i ordet, sproget, der således er "en urokkelig Mur mod al Idealisme: al Nægtelse af det Legemliges fornuftige Virkelighed". 21

Grundtvig tager afstand fra tanken om såvel total adskillelse som total identitet mellem natur og ånd. At der hverken er en uoverstigelig kløft eller fuldstændig identitet, gør han eksplicit opmærksom på i ovennævnte skrift: "At nu legemlig og aandelig ingenlunde er en Modscetning i den Forstand som Løgn og Sandhed, uagtet det dristig er blevet paastaaet, det indsee vi let; thi de ophæve og nægte ingenlunde hinanden, de lade sig forbinde i venlig Vexel-Virkning, hvilket forudsætter baade foelles Virkelighed og foelles Oprindelse". ${ }^{22}$ Problemet med naturfilosofien er, ifølge Grundtvig, at den overbetoner åndsaspektet i forhold til sjælsaspektet. Grundtvig fører med andre ord en tofrontskrig mod såvel idealister som materialister. Der er ikke nok legeme i den idealistiske tilværelsesforståelse, og denne manglende sans for legeme er skyld i, at materialismen vinder frem. At der er sund fornuft i legemet, udgør en grundakkord i Danne-Virke-skriftet. Sjæl-legeme-dualismen, som kendetegner Descartes' erkendelsesteorier, er fraværende i Grundtvigs erkendelsesteori. Grundtvig tænkte ikke todelt, men tredelt: Ikke legeme og sjæl, men legeme, ånd og sjæl.

Det interessante ved Grundtvig er ikke hans skarpe kritik af materialismen, den er så at sige forventelig, det opsigtsvækkende er derimod hans skarpe kritik af idealismen. Hans tofrontskrig kan følges som en rød tråd gennem en stor del af forfatterskabet. Som eksempel skal nævnes artiklen "Vor Tids Ungdom" fra 1850. Hvis man ifølge Grundtvig gør studier af kroppen til et spørgsmål om resultater, der kan udtrykkes i "Tal og Maal og Vægt", understøttes den fremherskende "aandløse og hjerteløse Betragtning af den saakaldte anorganiske (umælende og døvstumme) Natur". ${ }^{23}$ Det er ikke kun Descartes og La Mettrie, der har gjort naturen åndløs, megen teologi har ifølge Grundtvig "bidraget sit til at opelske og indfrede den vanhellige, aandløse og hjerteløse Betragtning af Menneske-Naturen". ${ }^{24}$ Med dette syn på menneskenaturen som fordærvet og naturen som død er der en alliance mellem teologernes opfattelse og

$\begin{array}{ll}20 & \text { DV II, 39 f. } \\ 21 & \text { DV II, 40. } \\ 22 & \text { DV II, 39. } \\ 23 & \text { Danskeren III, 381. } \\ 24 & \text { Danskeren III, 383. }\end{array}$


Materialisternes (Kropdyrkernes) Paastand, at alt det aandelige og hjertelige var fremmed for Menneske-Naturen (...) Thi da den saakaldte christelige Theologi (...) fraskrev Menneske-Naturen al aandelig Kraft og alt hjerteligt Værd, da gav man den i alle Maader Pokker i Vold og stræbde selv at trykke 'Aabenbaringens' Seigl paa hele den aandløse og hjerteløse Natur-Betragtning. ${ }^{25}$

Såvel den dominerende teologi som den materialistiske videnskab er for Grundtvig præget af et så hjerteløst syn på naturen, at det logisk måtte føre til valget mellem to forklaringer af tilværelsen: den idealistiske eller materialistiske:

Den luftige og den haandfaste, som kaldte dem selv den ideale og den reelle, og da den luftige Forklaring ved at have hele Virkeligheden imod sig, maatte falde af sig selv, saasnart Troen derpaa blev beleet, saa maatte den haandfaste Betragtning nødvendig blive seierrig. ${ }^{26}$

Men heldigvis har mennesket i sin natur en umiddelbar følelse og fornemmelse, som kan udtrykkes i ordet - "Aandens Sværd" - der som Skræp kun behøver at svinges to gange for at blæse begge sine "saakaldte aandelige Modstandere omkuld". ${ }^{27}$

Selv om stilen er knudret, er tanken klar: Hvad Grundtvig kritiserer, er $\mathrm{i}$ virkeligheden den enighed, der på ét afgørende punkt har eksisteret gennem århundreder mellem kristen teologi og naturvidenskaben, nemlig enigheden om, at naturen ikke har skabende potentiale i sig. I Grundtvigs optik har naturen et sådant potentiale, hvilket han søger at klargøre ved at tale om en særlig "nordisk NaturVidskab", der bygger på naturen og historien som to grundpiller. En sådan forudsætter, at man forlader de forvirrede begreber om "Natur som alt varende" - noget statisk - og "Historie som alt foregaaende" - noget dynamisk - og blander begreberne på en sådan måde, at "Overenstemmelsen af Natur og Historie kommer for Lyset". En nordisk natur-vidskab skulle ifølge Grundtvig fremme "en menneskelig Betragtning baade af Naturen og Historien", det vil sige se forholdet mellem natur og historie som et vekselvirkningsforhold. En sådan forståelse skal bidrage til "at klare den dunkle men sikkre, herlige og hellige Vexel-Virkning mellem Aand og Støv i det mageløse Menneske-Liv". ${ }^{28}$

Hvad Grundtvig søgte, var en tredje position mellem idealisme og materialisme og dermed en anden måde at forstå naturen på end den dominerende i såvel teologien som naturvidenskaben.

Danskeren III, $383 \mathrm{f}$.

26 Danskeren III, 384.

27 Danskeren III, 384.

28 Danskeren III, 377 og 382.
} 


\section{Om mennesket $\mathrm{i}$ verden}

Grundstrukturen i den antropologi, som Grundtvig udfolder i "Om Mennesket i Verden", er, at mennesket er indfældet i tre forhold, nemlig "Forholdene til hvad vi kalde: Legem, Aand og os selv". ${ }^{29} \mathrm{Hvad}$ Grundtvig kalder "os selv", kalder han også for sindet, sjælen og selvbevidstheden. Disse forhold beskriver og analyserer han i tre kapitler: "Om Menneskets legemlige Forhold", "Om Menneskets aandelige Forhold" og "Om Menneskets Forhold til sig selv". Ånden er ikke det samme som sjælen. De tre led er heller ikke sideordnet. Ånd og legeme indgår hver for sig i den menneskelige helhed, hvorimod sjælen er "den i Sandhed forbundne Bevidsthed af begge". ${ }^{30}$ Sjælen er det, der siger 'jeg' til 'sig selv', det normale menneskes bevidsthed om at være til som selvstændig person. Ånd og sjæl er to forskellige fænomener: Ånd bestemmer Grundtvig som en "levende, kraftig og virksom Forestilling", der ikke kan sanses, men kun erfares i selvbevidstheden, dvs. i sjælen. Selvbevidstheden er det erkendelsesmæssige sted, hvorfra afhandlingens forestillingsmønster udfolder sig. ${ }^{31}$

I et forarbejde til artiklen har Grundtvig en prægnant formulering af forholdet mellem legeme, ånd og sjæl:

Trende Forhold, hverken flere eller færre, ere fælles for alle. Forholdet nemlig til det Synlige uden for os, til det Usynlige over os og til os selv; vort Forhold til de udvortes Ting udtrykkes ved vort Legeme, vort Forhold til os selv bestaaer i vor Sjael, vor Forhold til det udvortes Usynlige betegnes ved vor Aand, og den virkelige Eenhed af disse tre Forholde, Tre-Eenigheden af Legem, Sjæl og Aand i Verden er Mennesket. ${ }^{32}$

For Grundtvig er det afgørende at få præciseret, at sjæl og ånd ikke forveksles. Ved sjæl forstår han menneskets forhold til sig selv, ved ånd forstår han menneskets forhold til usynlige kræfter. Sjæl betegner med andre ord bevidstheden om sig selv som legeme og ånd. Den menneskelige selvbevidsthed befinder sig dermed $i$ en tvetydig stilling. På den ene side er den sæde for åndelige indtryk, men på den anden side må disse indtryk altid fremstå under en sanselig form. Det betyder, at bevidstheden kun er sig selv bevidst "giennem blandede Forestillinger af sandselig Oprindelse, men med aandigt Præg". ${ }^{33}$

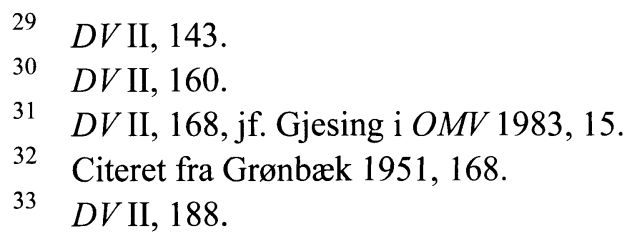


Mens ånden og legemet er sideordnet, kommer selvbevidstheden til gennem en historisk udviklingsproces. Legemet og ånden kommer før selvbevidstheden og kan fungere uden, hvad der er tilfældet hos dyrene og barnet, der endnu ikke har tilegnet sig et sprog.

Hvad legemlige og åndelige forhold angår, har vi ingen adgang til at tale om tingene i sig selv. Hvad vi kan klarlægge om den legemlige og åndelige verden, er derfor altid kun disse verdner $\mathrm{i}$ forhold til selvbevidstheden, der er knyttet til tid og rum. Det eneste, hvorom vi har en umiddelbar bevidsthed, er just vor egen selvbevidsthed, der pr. definition henviser til sig selv.

\section{Legemet - det dunkleste}

I en materialistisk model betragtes legemet som en maskine, $\mathrm{i}$ en idealistisk model som et redskab for ånden. Selv om Grundtvig indimellem falder tilbage til at omtale forholdet mellem ånd og legeme i idealistiske termer, søger han tydeligvis at frigøre sig fra såvel en materialistisk som en idealistisk sprogbrug, når han omtaler legemet. Samme bestræbelse finder man 150 år senere hos den franske filosof Maurice Merleau-Ponty, hvis kropsfænomenologi ligeledes udgør et forsøg på at bryde med de to klassiske måder at beskrive kroppen på. ${ }^{34}$ At Grundtvig søger en tredje position mellem en materialistisk og en idealistisk forklaringsmodel, betyder som sagt, at synet på legemet bliver kompliceret. I "Om Mennesket i Verden" gør han opmærksom på, at han ikke vil tale om legemet "som Redskab for en Aand", men derimod om "Foreningen i Mennesket af hvad der er deelt mellem Dyrene, og det af Foreningen udspringende Hoved Fortrin: Legemets Evne til Forestilling og Begreb om sig selv". ${ }^{35}$ I Grundtvigs optik er det yderst gådefuldt, at der kan opstå selvbevidsthed i et menneskelegeme. For undersøger man legemet ved hjælp af naturvidenskabens undersøgelsesmetoder, finder man ikke spor af ånd. Og alligevel kan der opstå selvbevidsthed. Hvordan kan det ske? Enten må legemet rumme en iboende mulighed for udvikling af selvbevidsthed, eller også må selvbevidsthed være en egenskab, der tilføres mennesket. Det er karakteristisk, at Grundtvig afslog at skulle vælge mellem enteneller. For ham er selvbevidstheden et produkt af såvel interne som eksterne faktorer. Den afgørende eksterne faktor er sproget, hvilket jeg vil uddybe senere.

For Grundtvig er selvbevidsthed en iboende mulighed i legemet, hvilket får ham til at kalde legemet for det dunkleste, det der mindst og 
sidst lader sig forklare. Selv om man besad alle fysikkens og matematikkens kundskaber, lod det sig ikke gøre at give en udtømmende beskrivelse af legemet, "thi man indseer let at Opløsningen er ingen Forklaring". ${ }^{36}$ Nok giver det nyttig viden at "opskiære og sønderlemme Liig”, men en sådan fremgangsmåde forklarer på ingen måde det levende legeme. ${ }^{37}$ Fænomenet liv kan nemlig ikke udledes af den døde krop. At ville forklare det levende ud fra det døde er for Grundtvig en endnu mere forrykt tanke, end at "ville begribe de enkelte Stykker af et Uhr, uden at have noget Begreb om det Hele, eller at ville føle sig for med en Haand, der ei kunde føle sig selv". ${ }^{38}$ Ligesom et ur, der går, rummer egenskaber, man ikke kan udlede af dets enkelte dele, rummer det levende legeme egenskaber, man ikke kan udlede af den døde krop. Grundtvig afviser således, at man kan forklare alt ved at adskille alt. Hvis det var tilfældet, ville døden være menneskets højeste triumf. "Naar vi derfor tale om Legemets Forholde, da mene vi nødvendig det levende, selvbevidste Legeme, ikke det afsjolede som er et Liig". ${ }^{39}$

En videnskab, der søger at forstå det "levende Legeme", må tage sit udgangspunkt $\mathrm{i}$ livet som ordningsprincip. "Hvorvidt man alt nu kunde være i Stand til at spore Overgangene fra det Livløse til det Livagtige, derfra til det Besjolede og igiennem Dyre-Rækken indtil Mennesket, veed jeg vel ikke, men det veed jeg, at først naar man begynder at eftergranske alle Tings Forhold til Livet og ordne dem derefter, først da kan man tale om en videnskabelig Inddeling og om et System i Natur-Historien". Men har alle legemer i verden noget tilfælles? Undersøgte man sagen, hævder Grundtvig i forlængelse af Herder, ville man sikkert finde ud af, "at de samme Egenskaber laae til Grund for Stenen, som yttre sig i Planten og røre sig i Dyret". ${ }^{40}$ Mennesket rummer alle de egenskaber, som findes i mineralriget, planteriget og dyreriget og udgør på den måde et mikrokosmos af makrokosmos.

Hvad Grundtvig her knytter an til, er en gammel forestilling om verden som et system af hierarkiske niveauer. Grundtvig inddeler naturen i fire riger: mineralriget, planteriget, dyreriget og menneskeriget, der også er fire bevidsthedsniveauer. Dermed bygger Grundtvig videre på en kosmologi, der ifølge den amerikanske idéhistoriker Arthur O.

\footnotetext{
36 DV II, 144.

37 DV II, 145.

38 DV II, 198.

$39 \quad D V$ II, 144.

$40 \quad$ DV II, 148.
} 
Lovejoy i Europa går tilbage til Platons dialog Timaios. I sin bog The Great Chain of Being (1936) hævder Lovejoy, at det at opfatte naturen som niveauer af stadig højere værensformer var indtil for bare 200 år siden antagelig den mest udbredte opfattelse af tingenes almene indretning. Med Lovejoys bog bliver man ført ind i en kosmologi, som fra oldtiden og frem til slutningen af 1700-tallet har udgjort en konstant.

Som Kim Arne Pedersen har påvist i artiklen "Skabt i Guds billede - Grundtvigs syn på mennesket i verden”, synes Grundtvig at være stærkt inspireret af den kosmologi, som bliver udfoldet i den tyske teolog Esaias Fleicshers store værk Naturhistorie, hvis 10 bind Grundtvig havde i sin bogsamling. I sin skildring af naturen brugte Fleischer trappen og stigen som metaforer for forbindelse mellem de forskellige niveauer: "Forbindelsen imellem de skabte Ting under Lignelse af en Trappe eller Stige". ${ }^{41}$ De fire trappetrins karakteristika kan opsummeres på følgende måde:

- Mineralriget

- Planteriget - som ud over mineraler har liv

- Dyreriget - som ud over mineraler og liv har bevidsthed

- Menneskeriget - som ud over mineraler, liv og bevidsthed har selvbevidsthed

Grundtvig beskæftiger sig i "Om Mennesket i Verden" med alle niveauer, om end han klart lægger hovedvægten på det fjerde niveau, hvor mennesket befinder sig. De øvrige bliver kun antydet. Om det første niveau siger Grundtvig undskyldende, at han jo ikke har forstand på fysik og matematik og derfor kun kan spørge, om ikke "Maal, Sammenhoeng og Omfang skulde være de Egenskaber der maae tænkes ved ethvert jordisk Legeme". ${ }^{42}$ Om dette første niveau, mineralriget, spørger han videre, "om ikke Skikkelsen er det eneste vi kan sige de livløse Ting have $i$ sig selv" ${ }^{43}$ Form er med andre ord fælles princip i mineralriget.

På det andet niveau er der kommet noget nyt til, som ikke var på det første, idet "Planten har i sig selv det Virksomme der kan frembringe Skikkelsen". ${ }^{44}$ Mens stenen ligger urørlig og tilsyneladende livløs på jorden, har planterne rødder i jorden og følger med deres akse lyset. En plante vokser ikke vilkårligt. Den orienterer sig mod solen. Blomstens drejning mod lyset er udtryk for en form for refleksivitet,

Citeret fra Pedersen 2009, 97.

42 DV II, 149.

43 DV II, 149. 
dvs. en evne til at tolke tegn fra dens omgivelser. ${ }^{45}$ Grundtvig spørger, "om ikke Plantens Vext og Duft forudsætter en vis, skiønt uvilkaarlig Sandsning, og om ikke Duften er en, ligeledes uvilkaarlig, men dog virkelig Livs Yttring?" ${ }^{46}$ Duften er for Grundtvig tegn på en åndelig virkelighed. Mens Grundtvig i omtalen af mineralriget ikke antyder en overgang mellem mineralriget og planteriget, peger han på blomsten frem for polyppen - som "den rette Overgang" til dyreriget. ${ }^{47}$

På det tredje niveau er der - ud over skikkelse og vækst - kommet noget nyt til, nemlig bevægelse og bevidsthed. Dyret er i den ydre verden blevet i stand til at bevæge sig frit, men også i det indre er der sket noget nyt. "Dyret er et besjoelet Legeme", siger Grundtvig, men dyret er ét med sin bevidsthed. Grundtvig antyder, at de forskellige dyr udtrykker forskellige sjælelige kvaliteter, hvilket kan eksemplificeres ved at tale om hunden som udtryk for hengivenhed og krokodillen for grådighed. Grundtvig hævder ligefrem: "Kunde vi bestemme Graderne i Dyrets Bevidsthed, da kunde vi afdele Dyre-Rækken videnskabelig". Grundtvigs videnskabsbegreb bygger på en bevidsthedshistorisk tilgang, hvor Sandsning, og alle livsytringer udgør "et tro Billede af Bevidstheden". ${ }^{48}$ Mens blomsten i Grundtvigs kosmologi danner overgang mellem planteriget og dyreriget, er det elefanten og slangen, der danner bro mellem dyreriget og menneskeriget, et synspunkt, der vil blive udfoldet senere.

Dermed er vi på det fjerde niveau, hvor det nye er selvbevidstheden. Hvor dyrene har bevidsthed, har mennesket selvbevidsthed. Mennesket evner at sige jeg til sig selv. Hvorledes udvikling af selvbevidsthed ytrer sig, kan iagttages hos barnet, der som nyfødt helt og holdent er i sine sansers vold. Derfor "maa en omhyggelig Iagttagelse af Barnet fra Fødselen af, til det lærer at kiende sig selv i Speilet, og sige jeg til sig selv, lære os hvorledes Sandsningen udvikler sig". ${ }^{4}$ Grundtvig peger med andre ord på, at der er et samspil mellem udvikling af bevidsthedslivet og sanselivet hos barnet såvel som hos mennesket som art. At sanselivet er mest udviklet hos mennesket, betyder, at et højere niveau kan forklare mere om et lavere niveau end omvendt:

Her see vi da, at det er af Planterne vi skal lære at kiende Jorden, Planterne igien af Dyrene, Dyrene af Mennesket, og hvor bagvendt man

Jf. Hoffmeyer 2009a, 16.

DV II, 149.

DV II, 150.

DV II, 150 .

DV II, 151.
} 
altsaa hidindtil for det meste har drevet Videnskabeligheden, da man vilde begribe det Større $i$ det Mindre, forklare det Høiere af det Lavere, det Levende af det Livløse, det Fornuftige af det Umælende, vi see, at allerede i Sandse-Verdenen driver Alt os tilbage til os selv, og Naturen afviser alle vore Spørgsmaal med det Tørre: spørg dig selv! ${ }^{50}$

Ingen videnskab kan ifølge Grundtvig give en umiddelbar erkendelse eller anskuelse af det evige eller af Gud. Mennesket kan ikke drive det videre end til "at kiende sig selv, og derfra slutte sig til Gud". ${ }^{51} \mathrm{Her}$ refererer Grundtvig til grundtanken i den store verdenskæde, som opererer med bevidsthedsniveauer, der er højere end menneskets.

Grundtvig afviste, at de højere niveauer kunne forklares udtømmende ved hjælp af discipliner rettet mod lavere niveauer. Hvis for eksempel fysikken betragtes som grunddisciplin for al videnskab, reduceres alt til det første niveau: mineralriget. Grundtvig fastholder, at en sådan form for videnskab snyder, fordi fremgangsmåden betyder, at livet selv - og hermed det levende legeme - sættes udenfor i en parentes.

Med et andet udgangspunkt gjorde Niels Bohr godt hundrede år senere et lignende synspunkt gældende. I artiklen "Biologi og Atomfysik" fra 1938 omtaler Bohr livet som et fænomen, der ikke kan udledes af stoffernes sædvanlige fysiske og kemiske egenskaber: "Det med livet uadskilleligt forbundne stadige stofskifte gør det endog umuligt at betragte en levende organisme som et veldefineret system af materielle partikler". Og han fortsætter med at tale om komplementaritet mellem de naturlove, der egner sig til at redegøre for de livløse legemers egenskaber, og så de biologiske lovmæssigheder: "I denne forstand turde selve livets eksistens, såvel hvad definition som iagttagelse angår, i biologien betragtes som en given forudsætning, som ikke nærmere kan begrundes". 52

Ifølge Bohr er begrebet 'bevidsthed' knyttet til begrebet 'liv', men hverken 'bevidsthed' eller 'liv' kan beskrives ved hjælp af naturvidenskabens sprog, det kræver et teleologisk sprog, et sprog der indbefatter begreber som intention og refleksivitet. I sin bog om Filosoffen Niels Bohr (2009) skriver David Favrholdt, at Niels Bohr betragtede begrebet 'liv' som et irrationelt fænomen i fysikken, og 'liv' kan derfor ikke reduceres til noget fysisk-kemisk og ikke indfanges ved hjælp af en fysisk-kemisk udforskning. Bohr taler ligefrem om "livets gåders bundløse karakter". ${ }^{53}$

DV II, 151.

DV II, 41.

Bohr 1959, 32.

Favrholdt 2009, 297. 
Den ungarske biokemiker Albert Szent-Gyorgyi har givet en malende beskrivelse af, hvad der sker, når man forsøger at forstå fænomenet liv ved at søge "nedad": "Mit videnskabelige liv bestod i en nedstigning fra højere til lavere dimensioner, drevet af ønsket om at forstå livet. Jeg gik fra dyr til celler, fra celler til bakterier, fra bakterier til molekyler, fra molekyler til elektroner. Historien har sin ironi, for molekyler og elektroner er slet ikke levende. På min vej løb livet ud mellem mine fingre". ${ }^{4}$

Men hvordan så forklare 'liv' og 'bevidsthed', hvis disse fænomener ikke kan forklares ved hjælp af fysisk-kemisk forskning?

\section{Håndfølelse og selvbevidsthed}

Grundtvig stiller det helt grundlæggende spørgsmål, om "Materien kan tænke". Hans eget svar er, at det kommer an på, hvilken tilstand materien er i, idet den både kan være livløs og være oplivet. Er der liv i materien, kan den "komme til at tænke, da Tanken ikke er andet end en Udvikling af Livs-Følelsen og naar Legemet kan med Tanken omfatte sig selv, er det sig selv bevidst, har en fornuftig, tænkende Sjæl". ${ }^{55}$ Der indgår således en psykologisk kategori i Grundtvigs beskrivelse af legemet. Legemet tilskrives intentionalitet og refleksivitet, det vil sige et jeg-perspektiv. I Grundtvigs antropologi er legemets evne til at udvikle selvbevidsthed ikke noget 'sjæleligt' i modsætning til noget 'fysiologisk'. Dog mener han ikke, at legemet i sig selv kan frembringe fornuften, men at den legemlige organisation ad naturens vej udvikler sig "i samme Forhold som Livet hvis Redskab den er, og vækker i Livets Tjeneste, paa sin høieste Punkt Fornuften". ${ }^{56}$ Det er med andre ord livet, og de erfaringer, det giver, der opvækker legemet til stadig højere udtryk, med fornuften som det foreløbige højdepunkt og livet selv som det egentlige, ikke omvendt

For Grundtvig hænger legemets evne til at tænke og begribe "sig selv" på det nøjeste sammen med håndens evne til at sanse og gribe. Hænderne og håndførelsen spiller en uhyre central rolle i Grundtvigs antropologi og psykologi. Hånden er nemlig redskabet for følesansen, som han anser for at være den vigtigste af de fem sanser. Når vi ser på sanserne, siger Grundtvig,

da maae Handerne strax tildrage sig vores Opmærksomhed, ikke alene som et Sandse-Redskab der staaer paa Grænsen af en vis Selv-

\footnotetext{
54 Hoffmeyer 1983, 123.

55 DV II, 156.

56 DV II, 156.
} 
stændighed, er paa en Maade udenfor Legemet, kan i en vis Afstand ligesom nøde Ting til at lade sig sandse, og kan sandse det hele Legeme, men og som Redskabet for den mest udviklede Sands, den, uden hvilken Sandsningen ikke kan fuldendes, give fuld Sikkerhed og bestemte Forestillinger; thi Sandsningen som begynder med en dunkel, ubestemt Følelse ved Berørelse, sluttes aabenbar i Haanden med den klareste og bestemteste Følelse, med den virksom blevne Følelse: Befølelse. $^{57}$

I intet andet skrift bliver hånden og håndfølelsen så indgående behandlet som i "Om Mennesket i Verden". Håndfølelsen er for Grundtvig den vigtigste sans. At kunne mærke verden og udskille sin egen krop som et objektivt element i denne verden er den psykofysiologiske forudsætning for jeg-dannelsen. Med hånden lærer vi at skelne det legem-lige fra det $u$-legemlige, det kendte fra det ukendte, det virkelige fra det uvirkelige. Det sker ved, at vi hele tiden efterprøver vores omgivelser og fører indtrykkene tilbage til legemet. Alt sammen ud fra den devise, at "hvad der er haandgribeligt det er saa virkeligt tilstæde som Legemet selv". ${ }^{58}$ Håndfølelsen er for Grundtvig en forudsætning for erfaring og fornuftsvirksomhed. Erfaringen bygger på sansninger, kropslige fornemmelser og følelser, som forstanden finder et mønster i. Sansning og fornuft er ikke, som hos Immanuel Kant, to adskilte erkendelsesevner, de indgår begge i en og samme erkendelsesproces, der begynder i sansningen og slutter i forstandens anerkendelse af de former eller dannelser, som skyldes sanseorganernes egenskaber.

\section{Elefantens snabel og barnets hånd}

For Grundtvig spiller hånd-følelsen en helt afgørende rolle for to udviklingsprocesser. Den ene er overgangen fra dyr til menneske, den anden overgangen fra det ikke-bevidste til det selvbevidste barn. Først overgangen fra dyr til menneske.

For Grundtvig er der hånden til forskel mellem mennesker og dyr. At dyret ikke har legemets evne til selvbevidsthed, hænger nemlig sammen med, at intet dyr har en forlab - et "Haand-Tag" - som mennesket. Hos intet dyr har man "fundet et Redskab for Følelsens Sands, der kunde giøre Haandens Tjeneste". ${ }^{59}$ Det er ved håndens hjælp, at mennesket rejser sig over dyrene. Hvad vi kan erfare er,

\footnotetext{
$57 \quad D V$ II, 147.

$58 \quad D V$ II, 147.

$59 \quad D V$ II, 155.
} 
at Haanden, som ei let lader sig bestikke med ingen Ting, er, til sikker Sansning en umisteligt Lem, og at een Fugl i Haanden, ikke alene for Nydelsens men ogsaa for Kundskabens Skyld, er bedre end ti i Luften, eller med andre Ord, at hvad man kan tage og føle paa, er ligesaadan til som vort eget Legeme, hvilket vi ingenlunde kan sige sige om alt hvad vi see og høre. Fremdeles maae vi agte, at det først er ved HaandTag vi ere i Stand til at sandse vort hele Legeme og overbevise os om dets Sammenhoeng, den Egenskab der skiller Legemer fra Skygger, saa det er Følelsens Sands vi skylde Begrebet om os selv. ${ }^{60}$

Det er vigtigere, end det måske synes ved første øjekast, skriver Grundtvig, for her står vi ved det punkt, "hvor Mennesket reiser sig over Dyret". ${ }^{61}$ Den tanke, at det er ved håndens hjælp, at mennesket rejser sig over dyrene, er Grundtvig på ingen måde ene om. Også Karl Marx tilkender hånden afgørende betydning. ${ }^{62}$ Men hvor Marx betonede forbindelsen mellem hånd og redskab, fremhævede Grundtvig forbindelsen mellem hånd og mund, dvs. sproget. Forenklet sagt lagde Marx vægt på hånden som et redskabsproducerende organ, mens Grundtvig pointerede håndens refleksive potentiale. Den problemstilling vender jeg tilbage til. Men først skal vi kaste et blik på Grundtvigs vurdering af en række dyr.

Selv om mennesket ved håndens hjælp rejser sig over dyrene, er der dyr, der er tættere på mennesket end andre dyr. Med andre ord: Der er dyr, der næsten har selvbevidsthed. Nærmest mennesket er ifølge Grundtvig slangen og elefanten. Det kan synes overraskende, at Grundtvig ikke nævner aben. Men aber står tydeligvis ikke i høj kurs hos Grundtvig, hvilket kommer til udtryk mangfoldige steder i forfatterskabet. Samme aversion finder man hos Herder, der tager afstand fra den idé, at aben og mennesket ligner hinanden. Samtidig glæder han sig over, at det guddommelige forsyn har bygget abens strubehoved således, at den ikke vil kunne benytte talens gave til at give udtryk for sine dyriske tanker! ${ }^{63}$

I modsætning til aben, der kun kan efterabe, har slangen stræbt efter at "forrykke Naturens Orden, og derved forrykt sig selv", hvilket har givet den evnen til "at tænke paa sig selv", ${ }^{64}$ Baggrunden for Grundtvigs syn på slangen er naturligvis Første Mosebog kap. 3. Grundtvig nøjes imidlertid ikke med at identificere slangen med

$\begin{array}{ll}{ }^{60} & D V \text { II, } 153 \mathrm{f} . \\ { }^{61} & D V \text { II, 154. } \\ { }_{62} & \text { Marx 1962, } 98 \mathrm{f} . \\ 63 & \text { Herder, citeret fra Pedersen } 2009 . \\ { }^{64} & D V \text { II, } 154 .\end{array}$


djævelen og som menneskets naturlige fjende, men fremhæver også, at slangen i Bibelen kaldes for "det klogeste af Markens Dyr". 65

Ligesom Fleischer peger Grundtvig på elefanten som et dyr, der står mennesket nær. Det skyldes, at elefanten har et håndlignende redskab. Elefantens snabel er det tætteste, man i dyreriget kommen foreningen af hånd og mund, $\mathrm{ja}$, elefanten har ifølge Grundtvig ligefrem "Haand og Mund i Eet". Det er denne intime forbindelse, der gør elefanten til et af de klogeste dyr, men end ikke den formår lige så lidt at tænke på sig selv "som et aarsgammelt Barn". ${ }^{66}$ Bevidsthedsmæssigt er elefanten og det nyfødte barn på samme udviklingstrin! Elefanten og det nyfødte barn har det til fælles, at de ikke har udviklet selvbevidsthed. Dermed rejses den anden problemstilling: Hvordan skal overgangen fra det ikke-bevidste til det selvbevidste barn forklares?

\section{Fra hånden til munden}

At barnet i modsætning til elefanten kan udvikle selvbevidsthed, kan forklares ved, at sanserne hos mennesket spiller sammen på en mere fuldstændig måde end hos dyrene. Grundtvig fremhæver, at der i mennesket som naturskabning intet nyt er i forhold til dyrene, "men kun en Forening af Alt som det i den høieste Grad findes deelt mellem Dyrene, og at det er i denne Forening og den derved mulige fuldstændige Sandsning, Legemets Selv-Bevidsthed udspringer paa Erfaringens Vei og avler Menneske-Forstand". ${ }^{67}$ Det er takket være denne forening i mennesket, af hvad der er delt ud mellem dyrene, at mennesket kan udvikle selvbevidsthed. Legemet formår med tankens hjælp at omfatte sig selv. Det er den elementære erfaring af legemets virkelighed, der er udgangspunkt for al sand erkendelse og udvikling af den menneskelige forstand og selvbevidsthed.

For at blive klogere på udviklingen af barnets selvbevidsthed kan man ifølge Grundtvig med fordel foretage "en omhyggelig Iagttagelse af Barnet fra Fødselen af, til det lærer at kiende sig selv $i$ Speilet, og sige jeg til sig selv". ${ }^{68}$ Uden på nogen måde at påstå at have forstået sagen i sin fulde sammenhæng mener Grundtvig dog at have dannet sig et vist begreb om den. Det kommer sig af, at han "paa det omhyggeligste har iagttaget det høistmærkværdige Billede af Skabelsen som

$\begin{array}{ll}{ }^{65} & D V \text { II, } 154 . \\ 66 & D V \text { II, } 155 . \\ { }_{67} & D V \text { II, } 156 . \\ 68 & D V \text { II, } 151 .\end{array}$


er tilsyne hos Barnet". ${ }^{69}$ Spædbarnet lever, som man ofte siger, fra hånden til munden. $\mathrm{Og}$ for Grundtvig danner dette udtryk basis for en hel filosofi om barndommen. Som Grundtvig ser det, udvikler barnet sig gennem tre stadier på livets vej: det første er begærets stadie, det andet selvfølelsens stadie og det tredje selvbevidsthedens stadie.

I barnets første udviklingsstadie er der en naturdrift, der får det til at gribe efter noget $i$ omverden. Barnet begynder sin tilegnelse af verden ved at gribe, hvad det kan få i hænderne. For: "Hænderne ere vore Redskaber for Følelsens Sands, og naar vi see noget som forlyster Øiet, da gribe vi gierne derefter, for, efter Omstændighederne, at forbinde eller forene det med os". ${ }^{70}$ Når barnet griber ud med hænderne, griber det ofte forgæves. For Grundtvig er det afgørende imidlertid ikke, om virkeligheden lever op til forventningerne, men at sjælen har en utrættelig evne og lyst til at gribe efter og forbinde sig med, hvad den til enhver tid finder adskilt fra sig. Lysten til at række ud efter noget kalder Grundtvig for begarlighed og ønsket om et nærmere forhold for tilbøjelighed. Begge dele er ytringer af følesansen: "det er Sjælens Følelse af en vis Sammenhæng mellem det Udvortes og Noget af Sit, som yttrer sig deri". ${ }^{71}$ Dette "Noget" er, som Uffe Jonas har gjort opmærksom på, ${ }^{72}$ afgørende. "Noget af Sit" refererer til den følelsesmæssige urforbindelse, der eksisterer, allerede inden barnet begærligt griber ud efter noget i omverden. Begæret er ikke i sig selv noget negativt, det er første og sidste udtryk for menneskets naturlige længsel mod forening - og forklaring.

Barnets rejse gennem alle de erfaringer, som legemet skal gøre, er lang. Udviklingen af selvfølelse er det andet stadie på livets vej. Det første spor af åndelig følelse hos sjælen er ifølge Grundtvig selvfølelse, og derfor må selvfølelse "være den aandige Grund-Følelse, der giør os til Mennesker". ${ }^{73}$ Det er selvfølelsen, der sikrer fornemmelsen af en sammenhæng, som udvikles i takt med, at barnet tilegner sig legemet. Udviklingen af selvfølelsen til en egentlig selvbevidsthed bringer barnet til det tredje stadie. Med udvikling af selvbevidsthed formår barnet, hvad elefanten ikke formår: at tænke på sig selv! Og det kan først ske, når barnet så at sige får modersmålet ind med modermælken. Barnet er jo ikke født medlem af sprogets fælles verden. Det

\begin{tabular}{ll}
\hline 69 & $D V$ II, 152. \\
70 & $D V$ II, 189-190. \\
71 & $D V$ II, 190. \\
72 & Jf. Jonas 1997, 130-136. \\
73 & $D V$ II, 191.
\end{tabular}


tager tid, normalt en 2-3 år, at erhverve sig de kompetencer, der skal til for at komme ind i den verden, som er usynlig, men dog hørlig.

Som sagt er det, ifølge Grundtvig, ved håndens hjælp, at mennesket rejser sig over dyret, men hånden alene kan ikke udvikle selvbevidsthed, den må have hjælp af munden, dvs. ordet som et medium for ånden. Med stor selvbevidsthed hævder Grundtvig i Skolen for Livet (1838): "Mig blev det givet at opdage den store Naturlov for Aandens Virkning og Forplantelse". ${ }^{74}$ Litteraturhistorikeren Vilhelm Andersen har sidestillet Grundtvigs opdagelse af det levende ord med H. C. Ørsteds opdagelse af elektromagnetismen. ${ }^{75}$ For Grundtvig er åndelig livskraft lige så virkelig som elektromagnetisk kraft. Og ligesom den fysiske kraft har sin tilstedeværelsesform, har den åndelige det også, nemlig i det "vingede Ord", der endnu "omsvæver os". 76

Grunden under Grundtvigs sprogsyn lægges i Danne-Virke. I "Om Mennesket i Verden" omtaler han "Ordet og Sproget", som det "levende Giærde mellem to Lunde". ${ }^{77}$ De to lunde er metaforiske udtryk for legemet og ånden, der forbindes af ordet og sproget. Grundtvig blev aldrig træt af at påpege sprogets dobbelte natur: at ordet på den ene side bæres frem af lydbølger, og på den anden side ikke kan reduceres til lyd. I "Om Videnskabeligheds Forhold til Erfaring og sund Menneske-Forstand" fremhæver han, at vi dagligt overbevises om vekselvirkningen mellem vor legemlige og åndelige tilværelse, "naar vi tale og høre, thi da giøre vi netop en Erfaring der paa det nøieste svarer til vor blandede Bevidsthed: vi erfare giennem Hørelsens Sands ikke alene noget Legemligt - Lyden - men ogsaa noget Aandeligt - Ordet - thi Ordet er jo ikke andet end det Aandelige der træder ud i Erfaringens Kreds og aabenbarer sig for Aander". ${ }^{78}$

\section{Hånd og mund}

I sidste instans er sproget det, der adskiller mennesket som art fra dyrene.

At Ord er det høieste Udtryk for Menneske-Livet, er Noget, det flygtigste Blik maatte kunne opdage (...), thi vi behøve blot at tænke os Menneskeslægten stum for i den blot at have et eget Abekatte-

\footnotetext{
$74 V U \mathrm{IV}, 232$.

75 Jf. Andersen 1924, 203. Korsgaard 1986, 108 og Christensen 2009, 889.

$76 V U \mathrm{IV}, 232$.

$77 \quad D V$ II, 160.

78 DV II, 40.
} 
Slags, eens i tusinde Ledd, uden fremskridende Udvikling, uden Daad og Historie. ${ }^{79}$

Her står aberne igen for skud. De kan kun efterabe og har dermed ingen historie. Mennesket derimod er et historisk væsen, som deltager i et uhyre stort eksperiment, der viser, "hvordan Aand og Støv kan giennemtrænge hinanden". ${ }^{80}$ Eller formuleret $\mathrm{i}$ et mindre højstemt sprog: Hvordan mund og hånd kan spille sammen.

Grundtvig er ikke alene om at pege på samspillet mellem hånd og mund som grundlæggende for udvikling af børns sprog. Inspireret af den russiske kulturpsykolog Lev Vygotskys arbejde i 1920'erne og første halvdel af 1930'erne blev der i den daværende Sovjetunionen gennemført en omfattende forskning, som dokumenterede en tæt forbindelse mellem fingrenes udvikling og udvikling af sprog. "Udviklingen af fingrenes bevægelser bereder ligesom grunden for den efterfølgende udformning af talen", skriver den russiske sprogforsker A. M. Koljtsova i bogen Barnet laerer at tale (1981). Hun henviser til, at neuropatologien og defektologien længe havde haft rapporter, "der peger på den nære forbindelse mellem håndens og talens funktioner", og opsummerer de eksisterende forskningsresultater på følgende vis: "De her anførte forskningsresultater gør det, efter vor mening, rimeligt at regne hånden til taleapparatet". ${ }^{81}$

Grundtvig havde ikke forskning at støtte sig til, men personlige erfaringer af almen karakter. Ifølge Grundtvig ved nemlig enhver mand, der har kysset en piges hånd, at hånd og mund har noget sammen, idet "den særdeles Følelse der udvikler sig i Haanden, allerede spiller paa Læberne, og søger sin Forklaring paa Tungen". ${ }^{82}$ Hånden står i et intimt forhold til sproget, bevidstheden og refleksionslivet: Fra det elementære forhold at gribe er der en forbindelse til det mere bevidste (selv-)forhold, at begribe. For Grundtvig er der en nærmest mirakuløs forbindelse mellem at gribe og begribe, mellem krop og sprog, mellem hånd og mund. Menneskets afgørende erfaring er det håndgribelige, og hånden er det organ, hvormed vi griber. Munden, dvs. sproget, er så at sige det organ, hvormed vi begriber. Hånd og mund hænger sammen på en måde, så den ene ikke kan være den anden foruden. Men der er også tale om et niveauskifte fra at gribe om til at begribe. Hvad hånden sanser og føler, er tale uden ord, der venter på at blive artikuleret $\mathrm{i}$ ord. Ifølge Grundtvig beror sprogets kraft og

\footnotetext{
$79 V U$ II, 278.

80 US V, 408.

81 Koljtsova 1981,139 f.

82 DV II, $152 \mathrm{f}$.
} 
mening på konkrete sanselige erfaringer. Ordet kan kun begribe, hvis det er knyttet til håndens griben, ordet kan kun være levende, hvis det er knyttet til det sanselige, kødelige og organiske liv i venlig vekselvirkning. Vejen fra virkeligheden til sproget går således gennem hånden $\mathrm{og} \mathrm{i}$ videre forstand menneskets legeme.

Fra at gribe om til at begribe sker der en bevidsthedsmæssig opstigning. Ordet er det vigtigste medium til at begribe verden, idet sproget har den højeste grad af bevidsthed knyttet til sig, nemlig selvbevidsthed. I et fragment fra Danne-Virke-tiden differentierer Grundtvig mellem at begribe noget legemligt og noget åndeligt:

Legemlige Ting siges vi at begribe, naar vi ere lige saa sikkre paa deres Tilværelse som paa vort eget Legemes, (...) Aandelige Ting siges vi at begribe, naar de er os lige saa visse som vor SelvBevidsthed og kan forene deres hele Sammenhæng med den. ${ }^{83}$

Selvbevidsthed er for Grundtvig kernen i kroppens artikulation med ånden. Bevægelsen skal imidlertid også gå den anden vej: fra sprogets begriben til håndens griben.

Lev Vygotsky, der står fadder til den såkaldte kulturhistoriske skole, udviklede i mellemkrigstiden en teori om samspillet mellem hånd $\mathrm{og}$ mund, der på visse punkter minder påfaldende om Grundtvigs. I sit hovedværk Tcenkning og sprog (1971) slog han fast, at "hverken den tomme hånd eller intellektet som sådan er noget værd". Ifølge Vygotsky er "den tomme hånd" et rent "naturvidenskabeligt begreb" og "intellektet som sådan" et rent åndeligt begreb. Men en sådan opfattelse kan ifølge Vygotsky ikke danne grundlag for en videnskabelig psykologi. Han vender sig på den ene side mod en rent behavioristisk opfattelse, der kommer til udtryk i formlen: tænkning er sprog minus lyd; og på den anden side mod en ekstrem idealistisk opfattelse, efter hvilken tanke og ord er fuldstændigt uafhængige fænomener. Ifølge Vygotsky har disse teorier det tilfælles, at de principielt er ahistoriske. Selv slår han til lyd for en historisk psykologi.

Vygotsky slutter bogen - og dermed sit forfatterskab - med at forholde sig til de berømte ord, der indleder Johannes-evangeliet: "I begyndelsen var ordet, og ordet var hos Gud, og Gud var ordet". Disse bibelord havde Goethe besvaret med Fausts stemme: "I begyndelsen var gerningen". Vygotsky er enig med Goethe i, at "gerningen" var begyndelsen, men han tager afstand fra Goethes ønske om "at værdiforringe ordet". I forhold til handlinger repræsenterer ordet for Vygotsky et højere trin i menneskets udvikling. "Ordet var ikke i begyndelsen. I begyndelsen var gerningen. Ordet ligger nærmere ved 
udviklingens afslutning end ved dens begyndelse. Ordet er den krans, der kroner værket". 84

Selv om Grundtvig fastholdt, at ordet var med fra begyndelsen, ja, var begyndelsen, synes der at være stor overensstemmelse mellem Vygotskys beskrivelse af menneskets udviklingshistorie: fra "gerningen" til "ordet" som den krans, der kroner værket, og Grundtvigs beskrivelse af menneskets udviklingshistorie ved hjælp af begreberne ånd og legeme. I Grundtvigs optik har legemet endnu ikke begrebet ånden, men netop dét er opgaven, hvis endelige løsning er lig med historiens afslutning.

Her opkommer det rene Begreb af historisk Videnskabelighed, da Legemet giennem Tiden skulde forklares til at fatte Aanden, da Mennesket, ved efterhaanden at giennemskue sig selv, overbevistes om Synernes Sandhed, og udtrykde sin Vidskab i stedse klarere Ord og høiere Virksomhed, indtil selv Legemets Øine saae den Eviges Herlighed, og sænkede sig over Tid og Rum i det uindskrænkede Lyshav. $^{85}$

For Grundtvig er historien én stor erkendelsesproces. Hvad det gælder om, er "efterhånden" at kunne gennemskue sig selv og formulere de nye indsigter i stedse klarere ord. Med andre ord: Hvor der er mørke, skal der blive lys! En vigtig kilde til mere lys er ifølge Grundtvig større indsigt i samspillet mellem sjæl og legeme, sandhed og skønhed: "den hele Tid maa kaldes historisk, thi den staaer egenlig som et Spørgsmaal om, hvorvidt og hvorledes Sjæl og Legeme, Sandhed og Skiønhed, høre sammen, og ved at besvare dette Spørgsmaal bliver den kosmo-logisk: oplyser Verdens Vilkaar, og lignelseviis TheoLogisk, da det forklarede Menneske billedlig viser, hvad Gud virkelig maa vare". ${ }^{86}$

Grundtvig forholdt sig ikke direkte til Darwins afstamningsteori, som siger, at alle nulevende arter er modifikationer af tidligere livsformer, og at vi alle i den sidste ende gennem en uendelig kæde af generationer medstammer fra én og samme oprindelige urform for liv. Men sandsynligvis forholdet han sig indirekte til teorien, da han i et foredrag på Marielyst Højskole i 1862 fremhævede:

Vi er alle Mennesker, og ikke Dyr, Folk og ikke Fæ, saa at selv da vi laae og pattede og kunde ingen Ting sige, var vi dog ikke Patte-Dyr, men Patte-Børn, menneskelige Patte-Børn, saa at naar de Sprænglærde vil bilde os ind, at vi ikke er bedre end Hunde-Hvalpe og Katte-

\footnotetext{
84 Vygotsky 1971, 411.

85 DV II, 163.

86 DV II, $200 \mathrm{f}$.
} 
Killinger, fordi vi patter ligesom de, da kunde de ligesaa godt sige, vi var ikke bedre end Kyllinger og Giæslinger, fordi vi gaaer paa to Ben ligesom de. ${ }^{87}$

Det er Darwins store fortjeneste, at han gav et solidt videnskabeligt grundlag for udviklingslæren og en ny forklaring på udviklingens mekanik, senere er denne mekanik blevet udbygget med læren om genetik. ${ }^{88}$ Grundtvigs udviklingslære adskilte sig på afgørende vis fra Darwins, idet han fokuserede på bevidsthedens udvikling. Grundtvig erkender dog, at en bevidsthedshistorisk tilgang til studier af dyreriget endnu ikke er fuldt udviklet, men han hævder fortrøstningsfuldt, at det må være muligt.

At et saadant System endnu mindre end Rom kan bygges paa een Dag, følger af sig selv, men bygges maa det kunne efterhaanden, dersom vi kun kan opdage hvorledes det har sig med Sandsningen, og den hele sandselige Livs Yttring paa sin hoieste Punct, samt i hvad Orden Udviklingen gaaer for sig, og det kan vi opdage, dersom Sandse-Livet er paa sit Høieste i Mennesket. ${ }^{89}$

For Grundtvig er naturens verden opbygget som en trappe, hvor de enkelte trin rummer hver deres kvaliteter. Som nævnt er bevidsthed en kvalitet, der kendetegner dyreriget, men alle dyr har ikke samme grad af bevidsthed. Ved at studere dyrenes bevidsthed måtte det derfor, ifølge Grundtvig, være muligt at udarbejde en videnskabelig klassificering af dyrearterne i forhold til hinanden. Men selv om Grundtvigs udviklingslære synes uforenelig med Darwins, ville Grundtvig sikkert have nikket anerkendende til Darwins slutreplik i On the Origin of Species, hvor han fremsætter en slags skabelsesteologisk tydning af naturen:

Der er Storhed i det Syn paa Livet, at det, med dets forskjellige Kræfter, af Skaberen oprindelig er bleven nogle faa eller en enkelt Form indblæst, og at, medens denne vor Klode har rullet rundt efter Tyngdens bestemte Lov, have utallige Former, højst skjønne og højst vidunderlige, fra en simpel Begyndelse udviklet sig og udvikles endnu. ${ }^{90}$

\section{Epilog}

Hvorvidt Darwin med sin udviklingslære har givet en udtømmende forklaring på evolutionen, er stadig et omdiskuteret spørgsmål. I den

Grundtvig 1956, 61.

Jf. Bowler 2009.

DV II, 150.
}

Darwin 1872, J. P. Jacobsens oversættelse. 
diskussion er det, ifølge biokemikeren Jesper Hoffmeyer, vigtigt at skelne mellem afstamningsteorien og selektionsteorien. Mens det nemlig ikke står til diskussion, at alle nutidige arter, herunder homo sapiens, er modificerede udgaver af tidligere livsformer, foregår der med Jesper Hoffmeyers ord "ikke desto mindre fortsat en kompetent diskussion om, hvorvidt den naturlige selektion er en fyldestgørende forklaring på evolutionen". ${ }^{91}$ Hoffmeyer finder det ubestrideligt, at Darwins udviklingslære kan forklare meget om livets udvikling, men han sætter spørgsmålstegn ved, "om Charles Darwin egentlig forklarer evolutionen som et totalt fænomen". Teorien om den naturlige udvælgelse forklarer på overbevisende måde, hvordan der sker en udryddelse af de utilpassede, men den forklarer ikke, hvorfor naturen hele tiden skaber noget nyt. Den naturlige selektion var, ifølge Hoffmeyer, en effektiv mekanisme i den tidlige ende af evolutionen, men jo mere raffinerede dyr og planter bliver, jo flere faktorer kommer der i spil. "Og i de senere stadier af evolutionen, er denne kompleksitet så stor, at den simple model bliver utilstrækkelig". ${ }^{2}$

"Måske er biologiens fejl, at den har halshugget naturen", skriver Hoffmeyer i Naturen $i$ hovedet fra $1984 .{ }^{93}$ Siden har han ligget $\mathrm{i}$ konstant krig med darwinismen, som han finder er blevet en dogmatisk isme, der gør det tvivlsomt, om Darwin overhovedet ville kalde sig darwinist. Darwin opererer nemlig med eksistensen af en "stræben" $i$ naturen, en "stræben", som nutidens darwinister ikke vil vedkender sig. ${ }^{94}$ I hvert fald ikke officielt. En afgørende forskel mellem Darwin og neodarwinisterne er ifølge Hoffmeyer, at Darwin tilkender naturen 'intention', hvad neodarwinisterne ikke gør. Darwinismen har ifølge Hoffmeyer langtfra en overbevisende forklaring på, "at mennesket har et jeg. Darwinisternes eneste forklaring er, at den menneskelige bevidsthed og vores intentionalitet er en slags blår i øjnene”. Men det svarer til at sige, "at alt, hvad der betyder noget for mennesket: drømme, begær og længsel - er en illusion". 95

I Darwin-året 2009 rejste Hoffmeyer spørgsmålet: "Hvorfor er biologien ikke lige så vel en åndsvidenskab?" Nok har vi siden Darwin vidst, at mennesket er et produkt af naturen, men "er det virkelig tænkeligt, at en i bund og grund åndløs natur har kunnet frembringe et menneske?" spørger Hoffmeyer. “Anser man måske menneskets ånde-

\footnotetext{
91 Hoffmeyer 2009b, 6.

92 Hoffmeyer 2009a, 16.

93 Hoffmeyer 1984, 25.

94 Hoffmeyer 2009b, 6.

95 Hoffmeyer 2009a, 16.
} 
lige dimension for en slags lamperøg, så at ikke blot naturen, men også mennesket er en 'hovedløs' maskine? Men i så fald er videnskaben vel selv en del af lamperøgen?" I I sin seneste bog Tro på tvivl (2009) spørger han videre: "Har mennesket en sjæl?" Og svarer: "Givet er det i hvert fald, at vi kan have sjoclekval". ${ }^{97}$ Ifølge Hoffmeyer har ordet sjæl været mere eller mindre fraværende i videnskab og filosofi, ja, oven i købet i teologi, i meget lang tid. "Noget tyder på, at sjælen er et særdeles ømt punkt i vores selvforståelse. Og årsagen er indlysende, for ordet dækker over en side af menneskelivet, som naturvidenskaben har afvist som fiktiv". ${ }^{98}$ Og han fortsætter: "Da naturvidenskaben afskaffede sjælen sammen med res cogitans, glemte den prisen. Man kan ikke fornægte menneskets sjælelige eksistens uden at tegne et billede af mennesket, som ingen af os kan genkende os selv i". ${ }^{99}$ Som naturvidenskabsmand er det meget mod Hoffmeyers vilje, at han ser sig nødsaget til at give fundamentalisterne ret: "Naturvidenskaben snyder på vægten, hvis den påstår, at teorien om naturlig udvælgelse har løst gåden om livsformernes uafviselige teleologiske karakter. Det betyder vel at mærke ikke, at den naturlige udvælgelse så er et falsum, eller at afstamningsteorien kan afvises". ${ }^{100}$ Men i Hoffmeyers optik betyder det, at naturlig udvælgelse ikke kan stå alene som forklaring på evolutionsprocessen.

Hoffmeyer hævder, at vi er "nødt til at tilskrive naturen evnen til at tolke tegn i deres omgivelser". ${ }^{101}$ Ligesom Grundtvig henviser til blomstens duft som en livsytring, henviser Hoffmeyer til blomstens drejning mod lyset som udtryk for en form for refleksivitet, der sætter blomsten i stand til at afgøre, at noget er bedre end noget andet. ${ }^{102}$ Det er med andre ord ikke kun mennesket, der evner at tolke, det er en generel egenskab ved naturen. "Læring og kommunikation er i den grad centrale byggesten i det levendes natur". ${ }^{103}$ Et af de fænomener, som ifølge Hoffmeyer gør evolutionens senere faser meget mere komplekse end de tidlige, er udviklingen af sproget: "At menneskene erhvervede et talesprog, som de lidt efter lidt lærte sig at bruge til kommunikation af mere abstrakte ideer, er en af evolutionens største gåder”. Med tiden har vore forfædre været i stand til at øge komplek-

\footnotetext{
96 Hoffmeyer 2010, 12.

97 Hoffmeyer 2009, 25.

98 Hoffmeyer 2009, 25.

99 Hoffmeyer 2009, 37.

100 Hoffmeyer 2009, 159.

101 Hoffmeyer 2009a, 16.

102 Jf. Hoffmeyer 2009a, 16.

103 Hoffmeyer 2009b, 6.
} 
siteten af det kommunikerede indhold, og selektionen har præmieret individer, hvis hjerne havde let ved denne nye slags kommunikation, for "dengang som nu har det været nyttigt - og charmerende - at være 'godt skåret for tungebåndet"," ${ }^{104}$

Hoffmeyer nægter på den ene side at skulle vælge mellem at tro på en natur, der er fuldstændig umulig at føle sig hjemme i som åndeligt væsen, og på den anden side, at vi har fået sjælen pustet ind af Gud. Der må være en tredje mulighed, nemlig at" lave en intentionalitetens naturhistorie". ${ }^{105}$ Selv om jeg ikke ønsker at tage Hoffmeyer til indtægt for Grundtvigs syn på 'mennesket i verden', er der en slående lighed mellem den betydning, som Hoffmeyer tillægger tegnprocesser, og den betydning, som Grundtvig tillægger ordprocesser. Ifølge Hoffmeyer foregår der semiotiske processer i naturens rige, men de optræder i en særlig avanceret udgave i menneskeriget, nemlig som sprog- og kommunikationsprocesser. "Når vi ser menneskets udviklingshistorie i dette lys, fremtræder talesproget som et magtfuldt semiotisk stillads, og efter alt at dømme var det opfindelsen af dette særlige stillads, der på afgørende vis bragte vore forfædre væk fra de øvrige primaters livsform. En ny dynamik blev skabt, hvilket gav anledning til, at mennesket i modsætning til andre dyr er historiske dyr, dvs. ændrer deres være- og levemåde $\mathrm{i}$ en fortløbende proces, en kulturel evolution". ${ }^{106}$ Om end sprogdragten er forskellig, synes der ikke desto mindre at være et slægtskab mellem Hoffmeyers tegnteori og Grundtvigs ordteori. Begge teorier bygger på en tredelt model, hvis ligheder og forskelle dog ligger uden for denne artikels rammer at analysere nærmere.

Sammenlignet med Grundtvig er det hævet over enhver tvivl, at Darwin står stærkest, når det gælder videnskabelige kendsgerninger vedrørende menneskets afstamning. Men arbejdet med at frembringe disse kendsgerninger var åbenbart ikke nok til at give Darwins liv mening og fylde. I sin selvbiografi skriver han:

Mit sind synes at være blevet til en maskine, som kværner almene love ud af store ansamlinger af kendsgerninger. Men hvorfor det har forårsaget en hentæring af den del af hjernen, som mine højere sanser alene er afhængig af, er mig ikke muligt at fatte. Et menneske med en hjerne, som var højere organiseret eller bedre opbygget end min, ville jeg ikke tro skulle have lidt således. Og hvis jeg skulle leve mit liv igen, ville jeg have gjort det til en regel at læse noget poesi eller lytte til noget musik mindst en gang om ugen. For måske kunne de dele af min

Hoffmeyer 2009, 243. 
hjerne, som nu er hentæret, således være holdt aktive gennem anvendelse. Tabet af disse sanser er tab af lykke, og er måske ødelæggende for intellektet, og endnu mere sandsynligt for den moralske karakter gennem afkræftelsen af den følelsesmæssige del af vor natur. ${ }^{107}$

Om end Darwins tilbageblik på sit eget liv ikke rokker ved de videnskabelige kendsgerninger, han har beriget menneskeheden med, peger han på et problem, som Grundtvig havde blik for.

\section{Forkortelser}

Danskeren: N. F. S. Grundtvig (1848-51), Danskeren. Et Ugeblad, I-IV, København.

DV I-IV: N. F. S. Grundtvig (1816-19), Danne-Virke, et Tids-Skrift, I-IV, København.

GSkv I-II: K. E. Bugge (udg.) (1968), Grundtvigs skoleverden i tekster og udkast, I-II, København.

PS I-IX: Svend Grundtvig m.fl. (udg.) (1880-1930), N. F. S. Grundtvigs Poetiske Skrifter, I-IX, København.

US I-X: Holger Begtrup (udg.) (1904-09), Nik. Fred. Sev. Grundtvigs Udvalgte Skrifter, I-X, København.

$V U$ I-X: Georg Christensen og Hal Koch (udg.) (1940-49), N. F. S. Grundtvigs Varker i Udvalg, I-X, København.

\section{Litteraturliste}

\section{Vorker af Grundtvig}

Begtrup, Holger (udg.) (1904-09), Nik. Fred. Sev. Grundtvigs Udvalgte Skrifter, I-X, København

Bugge, K. E. (udg.) (1968), Grundtvigs skoleverden i tekster og udkast, I-II, København.

Christensen, Georg og Koch, Hal (udg.) (1940-49), N. F. S. Grundtvigs Varker i Udvalg, I-X, København

Grundtvig, N. F. S. (1813), Krønikens Gienmaele, København.

- (1816-19), Danne-Virke, et Tids-Skrift, I-IV, København

- (1848-51), Danskeren. Et Ugeblad, I-IV, København.

- (1956), Taler paa Marielyst Højskole 1856-71, København.

Grundtvig, Svend m.fl. (udg.) (1880-1930), N. F. S. Grundtvigs Poetiske Skrifter, I-IX, København.

\section{Voerker af andre forfattere}

Andersen, Vilhelm (1924), Illustreret dansk Litteraturhistorie, III, København. 
Bohr, Niels (1959), Atomfysik og menneskelig erkendelse, København.

Bowler, Peter (2009), Evolution. The History of an Idea, California.

Christensen, Dan Ch. (2009), Naturens tankeloeser. En biografi om Hans Christian Ørsted, København.

Darwin, Charles (1859, da. 1872), On the origin of species, London.

- (1871, da. 1874-75), The descent of man, and selection in relation to sex, , London.

Favrholdt, David (2009), Filosoffen Niels Bohr, København.

Gjesing, Knud Bjarne (1983), "Indledning" i N. F. S. Grundtvig: Om Mennesket $i$ Verden - med indledning og noter ved K. B. Gjesing, Herning.

Grønbæk, Villiam (1951), Psykologiske tanker og teorier hos Grundtvig, København.

Herder, J. G. (1877-1913), Ideen zur Philosophie der Geschichte der Menschheit, Sämmtliche Werke, Berlin.

Hjermitslev, Hans Henrik (2009), "Mellem Grundtvig og Darwin" i Dansk Kirketidende, København.

- (2009a), "Introduktion og læsevejledning" i Charles Darwin, Menneskets afstamning og parringsvalg, Aarhus.

Hoffmeyer, Jesper (1983), "Dialektoriet for sans og samling" i Per Warming (red.), Fremtidens videnskab. En debatbog om Grundtvigs videnskabssyn, København, 115-126..

- (1984, 1991), Naturen på hovedet. Om biologisk videnskab, København.

- (2009), Tro på tvivl. Kritik af religiøs og videnskabelig ufornuft, København.

- (2009a), "Darwin kan ikke forklare, at der er mennesker", Interview i Information, 7.-8. februar 2009.

- (2009b), "Lad os komme videre", Weekendavisen, 12.-20. marts 2009.

- (2010), "Kan dyr være moralske?", Information 9.-10.januar 2010.

Højskolesangbogen, 17. udgave, Odense.

Jensen, Bernard Eric (2003), Historie - livsverden og fag, København.

Jonas, Uffe (1997), "Tiden før selvet" i Ove Korsgaard (red.), En orm - en

Gud. Om mennesket $i$ verden, Odense.

Kemp, Peter (2001), Praktisk visdom. Om Paul Ricaurs etik, København.

Korsgaard, Ove (1986), Kredsgang. Grundtvig som bokser, København.

- (1997), "Om Grundtvigs kosmologi og psykologi" i Ove Korsgaard (red.):

En orm - en Gud. Om mennesket $i$ verden, Odense.

Koljtsova, M. (1981): Barnet loerer at tale, København.

Lindborg, Rolf (1999), Anden i naturen, København.

Lovejoy, Arthur O. (2005) The Great Chain of Being, Harvard.

Marx, Karl, (1962), "Den tyske ideologi” i Karl Marx Økonomi og filosofi. Ungdomsskrifter, Udvalg og indledning ved Villy Sørensen, København.

Merleau-Ponty, Maurice (1992), Kroppens fonomenologi, København.

Pedersen, Kim Arne (1989-90), "Grundtvigs natursyn" i Grundtvig-Studier 1989-90, København.

- (2009), "Skabt i Guds billede - Grundtvigs syn på mennesket i verden" i Mogens S. Mogensen (red.): Klimakrisen - hvad ved vi, hvad tror vi, og hvad gør vi?, København. 
Pedersen, Olaf (2000), Naturerkendelse og theologi i historisk belysning, Herning.

Taylor, Charles (1989), Sources of the Self. The Making of Modern Identity, Harvard.

Vygotsky, Lev (1971), Taenkning og sprog, II, København. 